\title{
"Dampak Daya Beli Konsumen Kendaraan Bermotor Terhadap Pajak Pertambahan Nilai (PPN) dan Pajak Penjualan Atas Barang Mewah (PPnBM)"
}

Dian Agustina, Firania Nazzilla Pramadista, Tatya Fara Regyna

\begin{abstract}
ABSTRAK
Penelitian yang kami lakukan disini dilatar belakangi atas berbagai masalah yang berkaitan dengan daya beli konsumen kendaraan bermotor terhadap PPN dan PPnBM. Penelitian ini dibuat bertujuan untuk mengetahui daya beli konsumen Pajak Pertambahan Nilai (PPNBM) dan Pajak Penjualan atas Barang Mewah (PPnBM) terhadap kendaraan bermotor. Metode yang digunakan dalam penelitian ini adalah metode deskriptif kualitatif dengan penelitian studi pustaka yang dilakukan mencari dengan mencari referensi dalam artikel dan mencari di internet. Hasil penelitian yang kami peroleh menunjukan bahwa secara serentak PPN dan PPnBM berpengaruh signifikan terhadap daya beli konsumen kendaraan bermotor, dan secara parsial PPN tidak berpengaruh terhadap daya beli konsumen kendaraan bermotor, sedangkan PPnBM berpengaruh signifikan terhadap daya beli konsumen kendaraan bermotor.
\end{abstract}

Kata Kunci: Pajak, PPNBM, PPN, Kendaraan Bermotor, Daya Beli Konsumen.

\section{ABSTRACT}

The research we conducted here was motivated by various problems related to the purchasing power of motorized vehicle consumers towards VAT and PPnBM. This study aims to determine the purchasing power of consumers of Value Added Tax (PPNBM) and Sales Tax on Luxury Goods (PPnBM) on motorized vehicles. The method used in this study is a qualitative descriptive method with literature research conducted by searching for references in articles and searching on the internet. The results of the research that we obtained show that simultaneously PPN and PPnBM have a significant effect on the purchasing power of consumers of motorized vehicles, and partially PPN has no effect 
on the purchasing power of consumers of motorized vehicles, while PPnBM has a significant effect on the purchasing power of consumers of motorized vehicles.

Keywords: Taxes, PPNBM, PPN, Motor Vehicles, Consumer Purchasing Power.

\section{PENDAHULUAN}

\section{Latar Belakang}

Kemajuan negara sangat kuat di bidang perpajakan. Pajak secara umum didefinisikan sebagai kontribusi kepada masyarakat untuk mendanai biaya simpanan masyarakat (public saving), yang merupakan sumber utama dana spekulatif masyarakat (public investment).

Para ahli ekonomi (analisis pasar) berasumsi bahwa tidak semua pengiriman uang ke dan dari sektor publik dapat diatur sebagai biaya pajak. Misalnya, beberapa relokasi ke sektor publik masih dipengaruhi harga. Dari sudut pandang ahli ekonomi, pajak adalah pertukaran sumber daya non-denda yang dikenakan berdasarkan asumsi tertentu tanpa adanya keuntungan secara langsung.

Dalam perpajakan modern, pemerintah mengumpulkan pajak dalam bentuk uang, sedangkan pajak tradisional pembayaran pajak dapat berupa pemberian barang atau bekerja. Pemungutan pajak dilakukan oleh organisasi publik seperti Direktorat Jendral Pajak di Indonesia, Kantor Pendapatan Kanada (Canada Revenue Agency) di kanada, atau Administrasi pendapatan Dalam (Interna Revenue Service/IRS) di Amerika Serikat. Ketika tidak membayar pajak, pemerintah dapat memberikan sanksi seperti denda, penyitaan aset, bahkan penahanan kepada orang-orang yang terbukti melakukannya.

Tujuan yang ingin dicapai adalah mengetahui daya beli konsumen Pajak Pertambahan Nilai (PPNBM) dan Pajak Penjualan atas Barang Mewah (PPnBM) terhadap kendaraan bermotor 


\section{LANDASAN TEORI}

\section{A. Pajak}

Pajak adalah tanda masyarakat. Dengan kata lain, pajak hanya ada di masyarakat. Masyarakat adalah sekelompok orang yang berkumpul pada waktu tertentu untuk tujuan tertentu. Bangsa adalah masyarakat dengan tujuan tertentu. Kelangsungan hidup suatu bangsa juga berarti kelangsungan hidup masyarakat dan kepentingan masyarakat. Dalam (Prabowo, 2019)

Seperti dalam Pasal (1) Undang-Undang Nomor 28 Tahun 2007 "Ketentuan umum dan tata cara perpajakan adalah berkewajiban untuk berkontribusi kepada negara yang terutang oleh orang pribadi atau badan yang bersifat memaksa menurut UndangUndang, tanpa mendapat timbal balik secara langsung dan digunakan untuk kepentingan negara sebagai kemakmuran rakyat.

Menurut Prof. Dr. Seomatri dalam (Ayu, 2016) Pajak ialah iuran rakyat yang diberikan kepada kas Negara berdasarkan pada peraturan perundang-undangan yang memaksa tanpa mendapatkan konpensasi secara langsung. Pengaturan ini memberkan gambaran bahwa dengan adanya pajak dapat menyebabkan dua keadaan berubah. Keadaan pertama adalah kemampuan individu menjadi berubah untuk mengendalikan sumber daya. Keadaan kudua adalah keuangan negara untuk penyediaan barang dan jasa publik semakin luas, karena termasuk kebutuhan masyarakat.

\section{B. Pajak Pertambahan Nilai (PPN)}

Pajak Pertambahan Nilai (PPN) adalah alternatif untuk pajak penjualan. Hal ini Pajak penjualan tidak lagi cukup untuk memperhitungkan kegiatan bersama, karena belum mencapai tujuan yang diinginkan untuk meningkatkan penerimaan negara, mendorong ekspor, dan mendistribusikan beban pajak secara merata (Sari et al., 2020) (Sari et al., 2020).

Sebagaimana dinyatakan dalam buku Soemarso "Akuntansi Suatu Pengantar" (2003: 269) dalam (WHASKITA, 2013).'PPN adalah suatu pajak yang dikenakan perusahaan apabila membeli Barang Kena Pajak (BKP)/JKP dari suatu Dasar Kena Pajak 
(DPP)". Pada dasarnya PPN digunakan sebagai pajak penjualan oleh pabean Indonesia, sehingga PPN pada dasarnya meliputi penyerahan seluruh barang dan jasa. Namun, PPN dipungut atas barang dan jasa tertentu karena alasan sosial, ekonomi dan budaya. Hal ini bertujuan untuk mendukung atau memajukan kegiatan ekonomi dan stabilitas ekonomi Indonesia.

\section{Pajak Penjualan atas Barang Mewah (PPnBM)}

Pajak Penjualan atas Barang Mewah (PPnBM) adalah pajak yang dikenakan atas penyerahan Barang Kena Pajak (BKP) yang tergolong mewah oleh pengusaha sehingga menghasilkan BKP barang mewah di dalam kepabeanan, selama kegiatan usaha dan di tempat kerja , atau pajak yang dikenakan atas impor BKP (Indonesia, 2009)(Indonesia, 2009)

PPnBM merupakan biaya tambahan selain biaya tambahan PPN. PPnBM dipungut atau dikenakan sekali oleh penguaha pada saat impor dan pada saat penyerahan BKP mewah. Dalm PPnBM, pengertian umum pajak tidak diketahui. Oleh karena itu, PPnBM yang telah dibayar tida akan dikreditkan kembali oleh PPnBM yang belum bayar.

\section{Daya Beli}

Daya beli adalah kemampuan membayar untuk mendapatkan apa yang diinginkan atau dibutuhkan (Kamus Besar Bahasa Indonesia; Balai Pustaka 2001: 241). Daya beli dimulai dari satu orang ke orang lain. Hal ini disebabkan oleh beberapa faktor, seperti dari status sosial, pekerjaan, penghasilan, dan lain-lain. Daya beli merupakan komponen penting dari Indeks Pembangunan Manusia (IPM), ukuran yang digunakan untuk menghitung pengeluaran (konsumsi) per kapita dari pendapatan seseorang (MeierStiglitz, 2001). Daya beli juga erat kaitannya dengan barang dan jasa. Ketika harga barang dan jasa relatif rendah, daya beli barang juga meningkat. Semua ini berlaku untuk metode bunga. 


\section{E. Kendaraan Bermotor}

Kendaraan bermotor adalah kendaraan yang digerakkan oleh peralatan teknik untuk pergerakkannya, dan digunakan untuk transportasi darat. Umumnya kendaraan bermotor menggunakan mesin pembakaran dalam, namun motor listrik dan mesin jenis lain juga dapat digunakan. Jenis-jenis kendaraan bermotor dapat bermacam-macam, mulai dari mobil, bus, sepeda motor, kendaraan off-road, truk ringan, sampai truk berat. Klasifikasi kendaraan bermotor ini bervariasi tergantung masing-masing negara. Dalam (Kendaraan Bermotor - Wikipedia Bahasa Indonesia, Ensiklopedia Bebas, n.d.)

\section{METODE PENELITIAN}

Penelitian ini bertujuan untuk mengetahui bagaimana daya beli konsumen terhadap PPN dan PPnBM pada kendaraan bermotor. Penelitian ini menggunakan metode kualitatif dengan penelitian studi pustaka yang dilakukan dengan mencari referensi dalam artikel dan mencari di internet dalam rangka analisis sistem. Alasan menggunakan metode penelitian studi pustaka adalah dapat mengumpulkan data untuk lebih mendukung objek dengan membandingkan teori yang ada dengan praktik yang ada di lapangan.

Subjek penelitian ini adalah tentang pajak konsumsi barang mewah terhadap daya beli konsumen kendaraan bermotor. Metode pengumpulan data yang digunakan dalam penelitian ini adalah mengumpulan dan mebandingkan data dari berbagai artikel, majaah, jurnal dan lain-lainnnya dengan browsing atau searching di internet. Penelitian ini menggunakan metode studi pustaka dengan mencari referensi di internet seperti jurnal majalah atau artikel dari berbagai data dan membandingkannya dengan teori yang sudah ada.

\section{PEMBAHASAN}

\section{A. PEMBAHASAN UMUM TENTANG PAJAK}

Pajak adalah sumbangan pribadi kepada negara menurut undang-undang yang berlaku, tetapi tidak mendapat balas jasa atau kompensasi secara langsung. 
Biaya pajak dipungut berdasarkan norma-norma hukum yang untuk menutupi biaya produksi barang dan jasa untuk mencapai kepentingan umum. Menolak membayar atau menghindari pajak pada umumnya bertentangan dengan hukum. Pajak dibedakan menjadi dua, yaitu pajak langsung dan pajak tidak langsung. Pajak dapat dibayarkan tunai atau bisa dalam pekerjaan dengan nilai yang sama atau setara.

Lembaga instansi pemerintah yang mengatur pemungutan negara di Indonesi adalah Direktorat Jenderal Pajak (DJP) yang berada di bawah Kementrian Keuangan Republik Indonesia.

\section{Pajak Menurut Para Ahli}

- Mardiasmo (2016:3) dalam (Suci, 2013)

Pajak adalah iuran yang dibayarkan warga negara kepada negara dan dikirim ke kas negara kemudian masuk ke kas negara tanpa mendapatkan timbal balik secara langsung.

- Prof. Dr. H. Rochmat dalam (Cahyani, 2019)

Pajak adalah iuran yang wajib dibayarkan kepada negara menurut peraturan perundang-undangan dengan tidak mendapat timbal balik yang secara langsung dan digunakan untuk membayar pengeluaran umum.

- Prof. Dr. P.J.A. Andriani, dalam buku Perpajakan Indonesia (2009:1) dalam (Suci, 2013)

Pajak adalah tagihan kepada negara yang dipaksa untuk membayar berdasarkan peraturan yang mengatur tentang pembiayaan pengeluaranpengeluaran umum yang berkaitan dengan fungsi Negara dalam penyelenggaraab pemerintahan.

\section{Fungsi Pajak}

Pajak memegang peranan yang sangat penting dalam kehidupan bernegara, terutama dalam pelaksanaan pembangunan. Pajak merupakan sumber pendapatan bagi negara untuk menutupi semua biaya, termasuk biaya pembangunan. Silahkan perhatikan berbagai fungsi pajak yang dijelaskan pada uraian di bawah ini.

\section{a) Fungsi Anggaran (Budgetair)}


Sebagai sumber pendapatan negara, pajak membantu membiayai pengeluaran-pengeluaran negara. Karena Negara membutuhkan dana untuk menjalankan misi negara sehari-hari dan melaksanakan pembangunan. Biaya ini dapat diperoleh dari penerimaan pajak.

b) Fungsi Mengatur (Regulerend)

Negara bagian dapat mengatur pertumbuhan ekonomi melalui kebijakan pajak. Fitur regulasi ini memungkinkan pajak untuk digunakan sebagai sarana untuk mencapai tujuan

\section{c) Fungsi Stabilitas.}

Dengan adanya sistem perpajakan, pemerintah memiliki sarana untuk menerapkan langkah-langkah stabilisasi harga untuk mengekang inflasi.

\section{d) Fungsi Redistribusi Pendapatan}

Pajak yang dikumpulkan oleh negara digunakan untuk mendanai semua kepentingan umum, termasuk dana pembangunan, untuk menciptakan lapangan kerja dan dengan demikian meningkatkan pendapatan masyarakat. Dalam (Cahyani, 2019)

\section{Jenis Pajak Di Indonesia}

Pajak merupakan sumber penerimaan Negara disamping penerimaan dari sumber migas dan non migas (Prabowo, 2019). Seperti dalam Undang-Undang Nomor 6 Tahun 1983 tentang Ketentuan Umum dan Tata Cara Perpajakan, pajak digunakan oleh rakyat untuk sebesar-besarnya kemakmuran negara tanpa imbalan langsung. Suka atau tidak suka, jelas dari teks undang-undang bahwa Anda harus membayarnya. Selain itu, Anda juga perlu mengetahui jenis pajak yang dibayarkan. Departemen Umum Pajak membagi pajak menjadi dua bagian., yaitu:

- Pajak pusat adalah pajak yang dikelola oleh pemerintah pusat melalui Biro Perpajakan Umum Kementerian Keuangan.

- Pajak daerah adalah pajak yang dikelola menjadi tanggung jawab pemerintah daerah, mulai dari pemerintah kabupaten/kota hingga pemerintah negara bagian. Dalam (Online Pajak, 2007) 
a) Jenis-Jenis Pajak Pusat

1 Pajak Penghasilan (PPh) adalah pajak yang dibayarkan oleh orang pribadi atau kelompok atas penghasilan yang diterima atau diperoleh selama pembaayarn pajak satu tahun.

2 Pajak Pertambahan Nilai (PPN) adalah pajak yang dipungut atas konsumsi barang atau jasa kena pajak di dalam daerah pabean. Perlu dicatat bahwa semua barang dan jasa dikenakan pajak kecuali ada aturan bahwa barang tersebut tidak kena pajak.

3 Pajak Penjualan atas Barang Mewah (PPnBM) adalah pajak yang dikenakan atas barang-barang selain kebutuhan pokok, yang dikonsumsi oleh orang pribadi tertentu, dikonsumsi oleh orang pribadi berpenghasilan tinggi, serta menunjukkan status, kesehatan, dan moralitas masyarakat, serta dapat dikonsumsi.

4 Bea Materai adalah pajak atas penggunaan surat-surat seperti surat kontrak/perjanjian, akta notaris, slip pembayaran, dan surat berharga, dan yang jumlah nominalnya melebihi jumlah tertentu.,

5 Pajak Bumi dan Bangunan (PBB) adalah pajak yang dipungut atas pemilikan atau penggunaan tanah dan bangunan. Padahal ini pajak pusat, tapi semua pendapatan PPB disetor ke pemerintah daerah. Dalam (Cahyani, 2019)

b) Jenis-Jenis Pajak Daerah

Berikut, beberapa jenis pajak yang dikenakan oleh Pemerintah Provinsi dan Pemerintah Kabupaten/Kota:

1 Pajak Provinsi, yang terdiri dari: Pajak Kendaraan Bermotor (PKB), Bea Balik Nama Kendaraan Bermotor, Pajak Bahan Bakar Kendaraan Bermotor, Pajak Air Permukaan, hingga Pajak Merokok. 
2 Pajak Kabupaten/Kota, yang terdiri dari: Pajak Restoran, Hiburan, Reklame, Hotel, Parkir, PBB, hingga Bea Perolehan Hak Atas Tanah atau Bangunan. Dalam (Cahyani, 2019)

\section{B. PEMBAHASAN UMUM TENTANG PAJAK PENJUALAN ATAS BARANG MEWAH}

Berdasarkan peraturan perundang-undangan yang berlaku di Indonesia, PPnBM adalah pajak yang dikenakan atas barang-barang yang tergolong barang mewah yang dilakukan oleh produsen untuk memproduksi atau mengimpor produk tersebut sebagai bagian dari usaha atau operasinya.

Dasar hukum PPnBM adalah Undang-Undang Nomor 8 Tahun 1983, dan barubaru ini Undang-Undang Nomor 42 Tahun 2009 beberapa kali diubah tentang Pajak Pertambahan Nilai Barang dan Jasa dan Pajak Konsumsi Barang Mewah (PPnBM).

Menurut Undang-Undang Pajak Pertambahan Nilai Nomor 18 Tahun 2000 yang tergabung dalam Undang-Undang Pajak Pertambahan Nilai Nomor 42 Tahun 2009, "PPnBM digunakan untuk menyajikan BKP yang tergolong barang mewah yang dilakukan oleh pengusaha di pabean. Pajak yang dipungut pada kendaraan mewah regional BCP mewah untuk bisnis atau pekerjaan atau impor.

PPnBM dan PPN diatur dalam undang-undang yang sama, karena PPnBM tidak dikenakan secara terpisah tanpa PPN. Pajak pertambahan nilai adalah pajak yang dipungut sebagai pajak pertambahan nilai atas barang atau jasa kena pajak yang didistribusikan oleh produsen kepada konsumen. Hampir semua barang konsumsi dikenakan PPN, sehingga PPN ditetapkan dengan tarif tetap 10\% dari harga jual. PPnBM lebih spesifik, tetapi dipungut hanya pada saat penyerahan Barang Kena Pajak yang tergolong barang mewah, dan tarifnya berbeda-beda tergantung jenis barangnya.

Apabila kendaraan diatas dalam jangka waktu 5 th sejak impor/ perolehannya dipindah tangankan, maka PPnBM yang terutang yang dibebaskan wajib dibayar ke kas negara dalam jangka waktu 1 bulan sejak kendaraan tersebut dipindahtangankan. Apabila dilanggar SKBKB + sanksi sesuai ketentuan yang berlaku(Prabowo, 2019). 


\section{Karakteristik PPnBM}

- PPnBM adalah pajak tambahan yang dikenakan atas barang mewah kecuali PPN.

- PPnBM hanya digunakan sekali. Lebih tepatnya, jika merupakan usaha impor atau pengadaan BKP yang tergolong barang mewah.

- PPnBM tidak dapat diperhitungkan karena golongan kena pajak ini adalah konsumen. Jika PPnBM dikreditkan, tujuan perpajakan belum tercapai dengan baik.

- Untuk ekspor, Anda dapat mengambil PPnBM yang dibayarkan pada saat pembelian. Padahal, PPnBM tidak bisa diperhitungkan. Dalam (Cahyani, 2019)

Perbedaan antara PPN dan PPnBM adalah PPN dikenakan pada semua mata rantai dalam jalur produksi dan distribusi barang atau jasa, sedangkan PPnBM adalah barang yang tergolong barang mewah pada saat impor atau barang yang tergolong barang mewah. dikumpulkan hanya sekali pada saat pengiriman. Pengusaha barang yang membuat barang atau jasa di dalam daerah pabean, kegiatan usaha, atau tempat kerja dicatat.

\section{Objek Pengenaan PPnBM}

Menurut penjelasan Pasal 5 ayat (1) Undang-Undang Nomor 42 Tahun 2009, Barang Kena Pajak yang tergolong barang mewah antara lain sebagai berikut:

1. Barang yang bukan untuk kebutuhan pokok.

2. Barang yang dikonsumsi hanya untuk menunjukkan status.

3. Barang yang dikonsumsi oleh orang tertentu.

4. Barang-barang yang umumnya dikonsumsi oleh mereka yang berpenghasilan tinggi. Dalam (Cahyani, 2019)

\section{Tarif Pajak Penjualan Atas Barang Mewah}

Mardiasmo (2011: 286) dalam (Cahyani, 2019) menyatakan bahwa tarif PPN barang mewah dapat ditetapkan untuk beberapa kelompok tarifnya minimal $10 \%$ dan maksimal 200\%. Pengaturan tarif atas golongan barang kena pajak yang 
tergolong barang mewah dan dikenakan pajak konsumsi atas barang mewah berdasarkan peraturan pemerintah. Sedangkan untuk jenis barang yang dikenai Pajak Penjualan atas Barang Mewah diatur dengan Peraturan Menteri Keuangan.

Tarif pajak sebesar 0\% (nol persen) dikenakan atas ekspor barang kena pajak yang tergolong barang mewah. PPnBM yang dibayarkan untuk pembelian BKP yang tergolong produk ekspor mewah dapat ditagih (refund).

\section{Jenis Kendaraan Bermotor yang Dikenakan Pajak Penjualan Atas Barang Mewah (PPnBM)}

Menurut Waluyo (2010: 78) dalam (Cahyani, 2019) merangkum implikasi dari Keputusan Menteri Keuangan ini, sebagai berikut:

a) PPnBM adalah pajak konsumsi atas barang mewah.

b) Sasis kendaraan adalah rangka kendaraan yang memiliki mesin pembakaran dalam dan/atau transmisinya serta as roda dan gandar terpasang yang dapat diubah menjadi mobil tergantung pada peruntukannya.

c) Kendaraan bongkar lengkap (selanjutnya disebut kendaraan CKD) adalah kendaraan bongkar lengkap yang mempunyai ciri-ciri pokok kendaraan dan termasuk perlengkapannya.

d) Kendaraan rakitan lengkap (selanjutnya disebut kendaraan CBU) adalah kendaraan yang mempunyai sifat-sifat esensial dari kendaraan yang bersangkutan tanpa dibongkar menjadi bagian-bagian tersendiri, termasuk perlengkapannya.

e) Kendaraan khusus adalah kendaraan yang dimaksudkan untuk tujuan khusus seperti golf, salju, pantai, mengemudi di daerah pegunungan, termasuk trailer dan semi trailer tipe hidup atau berkemah.

f) Kendaraan untuk mengangkut penumpang adalah kendaraan listrik untuk mengangkut penumpang, termasuk limusin atau station wagon.

g) Kendaraan pengangkutan barang merupakan tunggangan bermotor menggunakan kabin tunggal pada bentuk tunggangan bak terbuka atau bak tertutup, menggunakan jumlah penumpang nir lebih berdasarkan 3 (tiga) 
orang termasuk pengemudi yg dipakai buat aktivitas pengangkutan barang baik yg disediakan buat generik juga pribadi.

h) Kendaraan double cab adalah kendaraan penggerak kanan atau kendaraan listrik dengan double cab dengan bak terbuka, dengan tiga atau lebih penumpang termasuk pengemudi, dan berat total tidak lebih dari 5ton.

i) Angkutan umum adalah kendaraan yang digunakan untuk mengangkut orang dan barang dan terbuka untuk umum dengan tarif non-pekerjaan, baik di dalam ataupun di luar trayek. Plat dasar polisi 1 warna

j) Kendaraan Protokol Pemerintah adalah semua jenis kendaraan yang digunakan dalam rangka melayani pembantu presiden atau dalam rangka menyambut tamu negara, kecuali kendaraan yang digunakan oleh pegawai negeri atau pegawai.

k) Kendaraan patroli TNI/POLRI adalah kendaraan listrik untuk patroli TNI atau Polri.

Pengelompokan Barang Kena Pajak yang dikenakan PPnBM berdasarkan Peraturan Pemerintah (PP) serta jenis dan harga Barang Kena Pajak yang dikenakan pemeriksaan PPnBM ditetapkan oleh Menteri. Peraturan Menteri Keuangan (PMK).

Jika kendaraan yang ditunjuk diserahkan dalam waktu 5 tahun sejak impor atau pembelian, atau jika penunjukannya diubah sehingga penunjukannya tidak sesuai dengan penunjukannya, PPnBM yang dibayarkan pada saat impor atau pembelian menjadi tidak berlaku mulai tanggal ini. memperoleh. Dari transfer internal. Itu hanya dikenakan pajak selama satu bulan. Pembayaran yang bersangkutan atau namanya diubah sesuai dengan ayat (2) PP 12/2006.

\section{PAJAK KENDARAAN BERMOTOR}

Pasal 1 (12) Undang-Undang PDRD (Pajak Daerah dan Retaliasi) menyebutkan bahwa pajak kendaraan bermotor adalah pajak atas pemilikan dan/atau pengurusan kendaraan. (Faizal, 2010) menyatakan bahwa pajak jalan adalah pajak yang dipungut kepada pemilik mobil dan pajak jalan termasuk 4.444 pajak daerah. Kendaraan yang dimaksud adalah kendaraan berpenggerak empat roda dan gandengannya, digunakan pada semua jenis jalan lokal, dengan perangkat teknis berupa mesin atau perangkat lain 
yang membantu mengkonversi tertentu pembawa energi menjadi energi kinetik. Didorong (Waluyo, 2011: 238). Berbicara mengenai aspek pajak kendaraan bermotor, tidak terlepas dari berbagai kegiatan dari mobil. Mobil dan jalan tidak dapat dipisahkan (Yurida, 2012). Orang menggunakan mobil sebagai alat transportasi, dan tidak heran ketika mereka menggunakan mobil, pemerintah mengenakan pajak pada setiap orang yang menggunakannya. Pajak yang dipungut digunakan untuk pembangunan, pengembangan dan pemeliharaan jalan.

Menurut Bahl \& Linn dalam (Ayu, 2016) menyatakan bahwa jenis pajak yang dikeluarkan oleh mobil dapat diklasifikasikan sebagai berikut:

1. Pajak kendaraan bermotor (Automotive Taxation)

2. Pajak bahan bakar kendaraan bermotor (Fuel Taxation)

3. Pajak penjualan dan pemindahan kendaraan bermotor (Sales and Trafer Taxes on Motor Vehicles)

4. Pajak atas SIM (Annual License Taxes)

Pajak kendaraan progresif dikenakan atas nama dan/atau alamat yang sama dari keluarga yang sama. Oleh karena itu, wajib pajak yang memiliki banyak mobil mengubah nama mobil tersebut agar database tidak mencatat bahwa mobil tersebut benar-benar hanya satu orang.

\section{DAYA BELI KONSUMEN}

Daya beli adalah kemampuan seseorang untuk membeli suatu produk atau jasa. Menurut Fadilah dalam (Ayu, 2016), daya beli adalah kemampuan orang yang mengkonsumsi produk tersebut. Daya beli setiap orang berbeda-beda. Hal ini disebabkan oleh beberapa faktor seperti tingkat pendapatan, status sosial, dan profesi Anda. Menurut Soediyono dalam (Ayu, 2016), ada empat penyebab perubahan permintaan, yaitu:

\section{Perubahan pendapatan konsumen}

Untuk barang biasa, peningkatan pendapatan konsumen menggeser kurva permintaan konsumen ke kanan. Sebaliknya, ketika pendapatan turun, kurva permintaan bergeser ke kiri. Barang inferior, yaitu barang konsumsi yang tidak 
disukai konsumen dan hanya dikonsumsi secara paksa, jatuh dalam permintaan ketika pendapatan konsumen meningkat.

\section{Perubahan harga barang pengganti}

Jika suatu barang naik, maka permintaan akan barang substitusinya juga naik.

\section{Perubahan harga barang komplementer}

Meningkatnya harga salah satu barang, menyebabkan penurunan permintaan terhadap barang komplementernya.

\section{Perubahan cita rasa konsumen}

Preferensi konsumen dan perubahan preferensi mempengaruhi permintaan akan produk yang sedang tren saat ini. Ketika selera konsumen meningkat, begitu pula permintaan akan produk.

Penelitian Dyah, Fadilah dan Raja dalam (Ayu, 2016) mengenai pengenaan PPN terhadap daya beli. Hasil membuktikan bahwa pengenaan PPN berpengaruh negatif signifikan terhadap daya beli konsumen. Hal ini dikarenakan masyarakat secara langsung dibebankan pajak dalam setiap konsumsinya, dimana kondisi perekonomian yang belum mapan dan berbeda mengakibatkan masyarakat menekan konsumsinya sehingga daya beli menurun.

\section{E. PENGARUH PPN TERHADAP DAYA BELI KONSMEN KENDARAAN BERMOTOR}

PPN adalah pajak atas konsumsi barang dan jasa di dalam daerah pabean dan dipungut secara bertahap pada setiap jalur produksi dan distribusi. PPN sangat dipengaruhi oleh perkembangan transaksi komersial yang dikenakan PPN dan perilaku konsumen pada umumnya. Tarif PPN adalah $10 \%$.

Perpajakan PPN atas Barang Kena Pajak sudah dikenal oleh Wajib Pajak. Oleh karena itu, pengenaan PPN sendiri tidak mempengaruhi konsumen saat membeli kendaraan.

Berdasarkan penelitian yang telah dilakukan pada kedua objek yaitu mengenaipengenaan Pajak Pertambahan Nilai, menunjukan hasil yang tidak berpengaruh terhadap Daya Beli Konsumen Kendaraan Bermotor. Hal ini dikarenakan, jaman 
sekarang kendaraan bermotor memang sangat dibutuhkan oleh masyarakat sebagai alat transportasi dalam menjalankan aktivitas sehari-hari, sehingga pengenaan pajak pertambahan nilai yang tarifnya relatif kecil tidak mempengaruhi daya beli dari konsumen.

\section{F. PENGARUH PPnBM TERHADAP DAYA BELI KONSUMEN KENDARAAN BERMOTOR}

Pajak Penjualan atas Barang Mewah (PPnBM) adalah bagian dari PPN Barang Kena Pajak Mewah (BKP) yang dilaksanakan oleh pengusaha yang memproduksi, mengimpor, atau mengekspor Barang Kena Pajak Mewah di dalam Daerah Pabean di sekitar perusahaan. Atau karyanya. Pajak penjualan atas barang mewah dapat mempengaruhi kemampuan membeli konsumen terhadap nilai jual suatu barang, dalam hal ini kendaraan bermotor.

Pengenaan pajak penjualan atas barang mewah mempengaruhi daya beli konsumen kendaraan bermotor. Dengan kata lain, semakin tinggi harga jual suatu kendaraan mewah yang dikenakan PPN, atau semakin tinggi harganya dibandingkan dengan PPN, maka akan semakin besar pengaruhnya terhadap daya beli konsumen kenraan bermotor. Prestise dan daya beli yang menentukan pembelian mobil. Tidak semua orang memahami PPnBM dengan benar, namun tidak mengurangi niat beli karena membutuhkan ketenaran sebagai penegasan status sosial.

\section{KESIMPULAN}

Berdasarkan pembahasan di atas dapat di simpulkan bahwa kelompok Barang Kena Pajak terolong mewah yang dikenakan PPnBM diatur dengan Peraturan Pemerintah (PP), sehingga dapat di laksanakan pemungutan PPnBMnya, di tetapkan dengan Keputusan Mentri Keuangan (PMK). PPnBM mempengaruhi daya beli konsumen kendaraan bermotor. Semakin tinggi harga eceran suatu kendaraan yang dikenakan pajak penjualan barang mewah dengan tarif pajak yang lebih tinggi dari PPN, atau semakin mewah kendaraan tersebut maka semakin mempengaruhi daya beli kendaraan tersebut. 
Konsumen terpengaruh. Prestise dan daya beli yang menentukan pembelian mobil. Tidak semua orang memahami PPnBM dengan benar, namun tidak mengurangi niat beli karena membutuhkan ketenaran sebagai penegasan status sosial.

\section{SARAN}

Masyarakat dan pihak yang merupakan wajib pajak haruslah lebih proaktif dan mempunyai kesadaran untuk mengetahui berbagai hal yang berkaitan dengan pembayaran pajak dan aturan-aturannya. Sementara itu pemerintah harus bersikap bijak dengan tidak mengkorupsi uang pajak, dan sepenuhnya menggunakan hasil pungutan pajak untuk kepentingan masyarakat dan kemajuan bangsa, sehingga terjadi hubungan yang baik antara masyarakat dan Pemerintah dalam urusan pajak.

\section{DAFTAR PUSTAKA}

Ayu, I. P. R. (2016). Pengaruh Pajak Pertambahan Nilai dan Pajak Kendaraan Bermotor Tarif Progresif Terhadap Daya Beli Kendaraan di Denpasar. E-Jurnal Akuntansi Universitas Udayana, 15.2, 887-914.

Cahyani, R. L. (2019). Pengaruh Daya Beli Konsumen Terhadap Pajak Penjualan Atas Barang Mewah Kendaraan Bermotor Roda Dua. Universitas Sriwijaya, November. Indonesia, P. R. (2009). UNDANG-UNDANG REPUBLIK INDONESIA NOMOR 42 TAHUN 2009. In Kementrian Hukum dan Hak Asasi Manusia Republik Indonesia.

Kendaraan bermotor - Wikipedia bahasa Indonesia, ensiklopedia bebas. (n.d.).

Retrieved January 22, 2022, from

https://id.wikipedia.org/wiki/Kendaraan_bermotor

Online Pajak. (2007). Perpajakan di Indonesia. Journal of Experimental Psychology:

General, 136(1), 23-42. https://www.online-pajak.com/tentang-pajak/perpajakandi-indonesia-sejarah-sistem-dan-dasar-hukumnya

Prabowo, R. G. M. (2019). MEKANISME PPN DAN PPnBM. https://doi.org/10.31227/osf.io/shqmg

Sari, P. I. P., Jannah, F., \& Putri, Y. C. A. (2020). ANALISIS PAJAK PERTAMBAHAN 
NILAI PADA PERUSAHAAN ASIA GRAHA SUKSES MANDIRI

TULUNGAGUNG.

Suci, D. (2013). Pengaruh Penerapan. Journal of Chemical Information and Modeling, 53(9), 1689-1699.

WHASKITA, S. (2013). Penerapan Akuntansi Pajak Pertambahan Nilai (PPN). 